\title{
12. \\ TRANSFERI UMJETNINA I \\ VLASNIŠTVA UMJETNIČKIH ZBIRKI \\ U ZAGREBU PRIJE, TIJEKOM I NAKON \\ DRUGOG SVJETSKOG RATA*
}

\section{Iva Pasini Tržec i Ljerka Dulibić}

UDK: 347.78(497.5 Zagreb):339.14“194“

Prethodno priopćenje

Sažetak: Tekst se temelji na istraživanju razvoja međuratnoga umjetničkoga tržišta u Zagrebu kao rastućemu kulturnome središtu nekadašnje zajedničke države. Posebna pozornost pridaje se procesima transfera, translokacija, izmještanja i izvlaštenja umjetnina, do kojih je došlo uslijed primjene različitih mehanizama razvlašćivanja privatne imovine tijekom i nakon Drugog svjetskog rata, slijedom dvaju totalitarističkih režima. Predstavlja se djelovanje zagrebačkih društava i pojedinaca na domaćem i inozemnom tržištu umjetninama tijekom 1920-ih i 1930-ih godina, u kojemu se ogleda čitav panoptikum širih društvenih zbivanja koja su uvjetovala dinamičan transfer umjetnina i čitavih zbirki. Posebna se pozornost posvećuje kasnijim sudbinama privatnih zbirki formiranih u međuratnom Zagrebu. Ne samo oduzimanje židovske imovine tijekom Drugoga svjetskoga rata već i različiti mehanizmi razvlašćivanja koji su uslijedili u razdoblju poraća - uslijed doseljavanja, iseljavanja, sekvestracije i konfiskacije - imali su isti ishod. Disperzija umjetnina i brisanje tragova nekadašnjega vlasništva simptomi su koji svjedoče o povijesnom razdoblju u kojem se unutar normativnoga okvira podržavljenja gotovo cjelokupne privrede nastojalo uspostaviti uvid i kontrolu i u zadržano privatno vlasništvo, u kontekstu promijenjenih društvenih odnosa.

Ključne riječi: Zagreb, međuratno tržište umjetninama, Društvo prijatelja Strossmayerove galerije, privatne umjetničke zbirke, razvlašćivanje privatne imovine, transfer umjetnina, Drugi svjetski rat, poraće

tjedniku Svijet, koji je svojim ilustriranim prilozima gotovo programatski promovirao moderno društvo u različitim aspektima svakodnevice višsi građanskih slojeva, 1927. godine čitamo: 
Uporedo s razvitkom Zagreba, podizanjem modernih palača, stambenih kuća i ljetnikovaca, razvija se i ukus u unutarnjem uredjenju naših stanova. Utješljivo je, da se odstupa od starih šablona i da se domovi uredjuju ne samo sa gledišta praktičnosti, već i s puno smisla za lijepo, estetsko i skladno. Dakle - stilski. ${ }^{1}$

Stalna rubrika „Interieuri naših otmjenih domova“ sadržavala je profesionalne fotografije ponajboljih zagrebačkih stambenih prostora, uz gotovo didaktičke upute o otmjenom, lijepom, estetskom i skladnom uređenju, koje podrazumijeva ne samo prikladno arhitektonsko rješenje već i nabavu odgovarajućega pokućstva te naposljetku odabir i raspored umjetničkih predmeta. Ta težnja $\mathrm{k}$ „stilskom“ uređenju nesumnjivo je pridonijela ne samo razvoju likovne scene u Zagrebu već i živosti na tržištu umjetninama, prije svega djelima modernih, odnosno suvremenih umjetnika.

Većinu zagrebačkih privatnih zbirki činila su djela hrvatskih suvremenih slikara i kipara. Formirane su izravnim kupovinama u umjetničkim ateljeima i na izložbama prodajnoga karaktera ili u prvom zagrebačkom izložbenom salonu, Salonu Ullrich, koji je od prvoga desetljeća 20. stoljeća bio glavni promicatelj suvremene hrvatske umjetnosti, bitno određujući umjetnički i kulturni život zagrebačke sredine. ${ }^{2} \mathrm{U}$ inventarima Salona popisane su umjetnine i zabilježena imena kupaca, s točnim podatkom o vremenu realizirane kupovine, čineći tako dragocjen izvor istraživačima nacionalne povijesti umjetnosti. ${ }^{3}$

Takve specijalizirane prodajne kuće koja bi se bavila izlaganjem, promidžbom i prodajom djela stranih i starijih autora u Zagrebu tada nije bilo, no iz različitih izvora saznajemo i o trgovanju djelima tzv. starih majstora europskih slikarskih škola. Budući da je Strossmayerova galerija starih majstora u to doba funkcionirala kao ključno referentno mjesto za širok raspon znanstvenih i stručnih pitanja, arhivski dokumenti povezani s djelovanjem Galerije, od 1928. godine pod upravom Artura Schneidera, svjedoče i o djelima europskih starih majstora u privatnim zbirkama i na tržištu. ${ }^{4}$

U okrilju Galerije 1928. godine osnovano je Društvo prijatelja Strossmayerove galerije, čija je inicijativa za upotpunjavanjem zbirnog fonda Galerije potaknula brojne ponude različitih individualnih ponuđača iz svih krajeva tadašnje zajedničke države. ${ }^{5} \mathrm{U}$ tim ponudama, koje su pristizale nesmiljenim intenzitetom usporedno s Društvom i upravom Strossmayerove galerije, ogleda se čitav panoptikum širih društvenih zbivanja koja su uvjetovala dinamičan transfer umjetnina i čitavih zbirki s prostora cijele Jugoslavije. ${ }^{6}$ Osim uvida u

\footnotetext{
Svijet: ilustrovani tjednik, 2/(2. srpnja) 1927., br. 15, 11.

Usp. Žarka Vujıć, Salon Ullrich o stotoj obljetnici, Zagreb 2010.

3 Inventarne knjige Salona Ullrich čuvaju se u Arhivu za likovne umjetnosti HAZU. Usp. Darija Alujević, Andreja Der-Hazarijan Vukić i Jasenka Ferber Bogdan, Salon Ullich (http://dizbi.hazu.hr/ullrich).

4 Više o djelovanju Strossmayerove galerije pod upravom Artura Schneidera v. Ljerka Dulibić i Iva PAsini TRžEc, „Schneiderovi prilozi za Strossmayerovu galeriju starih majstora“, u: Zbornik radova znanstveno-stručnog skupa Hrvatski povjesničari umjetnosti 1. Artur Schneider (1879.-1946.) (ur. Ljerka Dulibić), Zagreb 2016., 71-79.

5 Više o djelovanju Društva prijatelja Strossmayerove galerije v. Lj. Dulibić i I. PAsini TRŽEC, „Akvizicije Društva prijatelja Strossmayerove galerije“, u: Imago, imaginatio, imaginabile. Zbornik u čast Zvonka Makovića (ur. Dragan Damjanović i Lovorka Magaš Bilandžić), Zagreb 2018., 281-301.

6 Usp. Lj. Dulibić, „Projekat 'Prenos kulturnih dobara u Alpe-Adria regionu u XX veku' ('TransCultAA')“, Stubovi baštine. Glasnik Zavoda za zaštitu spomenika kulture Niš, 3/2017., br. 3, 70-75, 74; IstA, „Međuratno jugoslavensko tržište umjetninama“, 8. posvet slovenskih umetnostnih zgodovinarjev. Provenienca, transferji in lastništvo umetnin. Sodobni izzivi za raziskovalce in lastnike, Maribor, 30. studenoga - 1. prosinca 2018.
} 


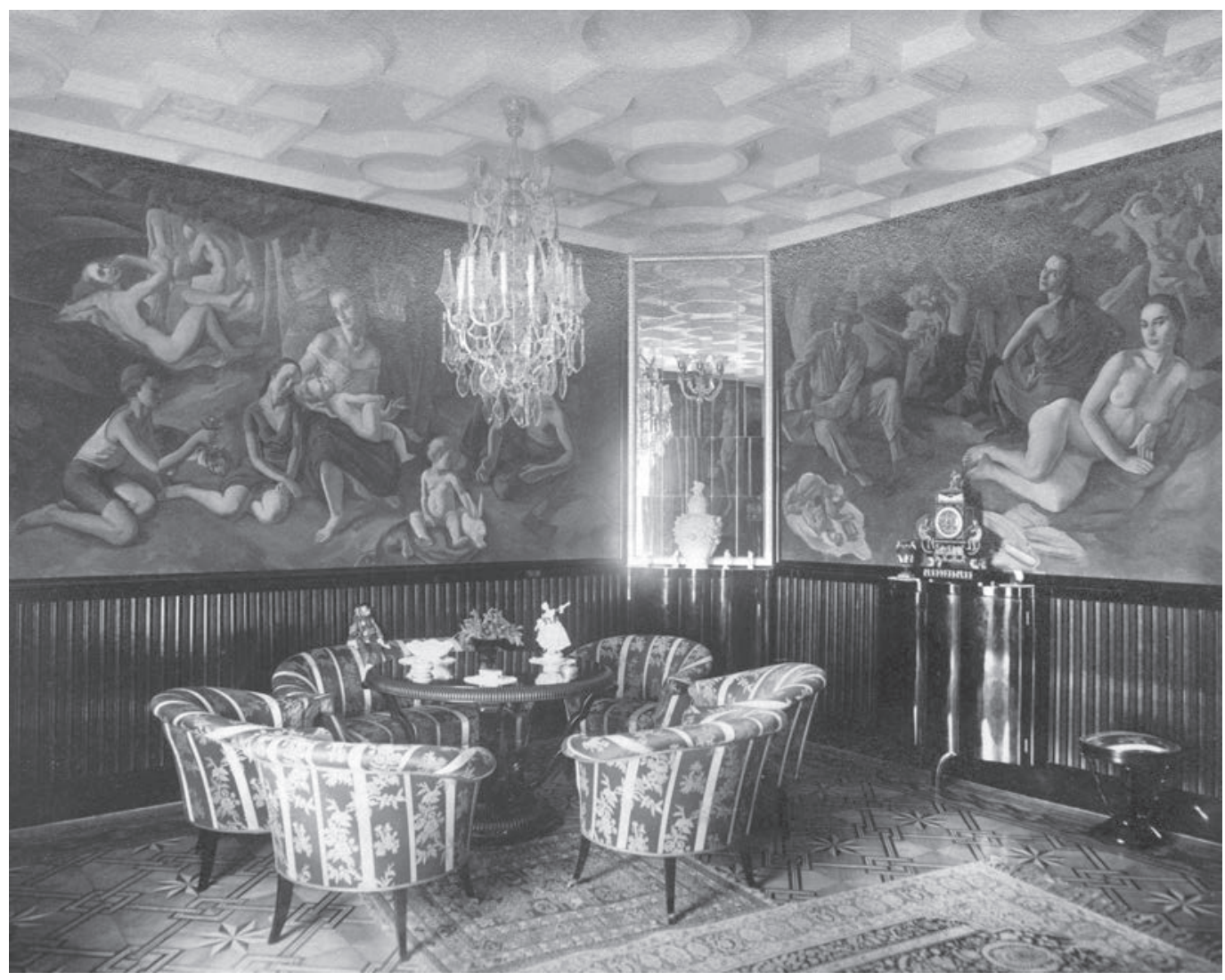

Sl. 1. Salon u stanu Roberta Deutscha Maceljskog sa slikama Milivoja Uzelca, 1925. (foto: Arhiv za likovne umjetnosti HAZU)

sadržaj tadašnjih zbirki, vrlo se često otkrivaju i razlozi prodaje, uglavnom potaknuti teškom osobnom situacijom. Danas je teško identificirati slike takvih individualnih ponuđača - one u pravilu nisu bile kupljene jer bi uprava Društva i Galerije ustanovila da nemaju „dostatnu umjetničku vrijednost“ ili bi, pak, vrijednost ponuđenih umjetnina, unatoč nepovoljnim okolnostima prodaje, još uvijek umnogome prelazila ipak podosta skromne mogućnosti Društva.

Društvo je isprva nabavljalo ustaljenim kanalima, kakvi su u to doba prevladavali na domaćem tržištu umjetninama. Uobičajen način nabave umjetnina bile su prodajne izložbe, bilo one koje su priređivali domaći slikari ili, pak, gostujuće iz inozemstva. Društvo se, međutim, vrlo brzo orijentiralo na nabave na međunarodnom umjetničkom tržištu. Ukupno je za vrijeme svoga djelovanja Društvo za Strossmayerovu galeriju nabavilo 11 slika. ${ }^{7}$ Iz odluka, postupaka i rasprava na odborskim sjednicama vidljivo je da su pojedini članovi Društva bili vrlo dobro upoznati s umjetničkim tržištem u susjednim većim središtima. ${ }^{8}$

7 Više o nabavljenim slikama v. Lj. Dulibić i I. PAsıni Tržec, „Akvizicije Društva prijatelja Strossmayerove galerije“. 


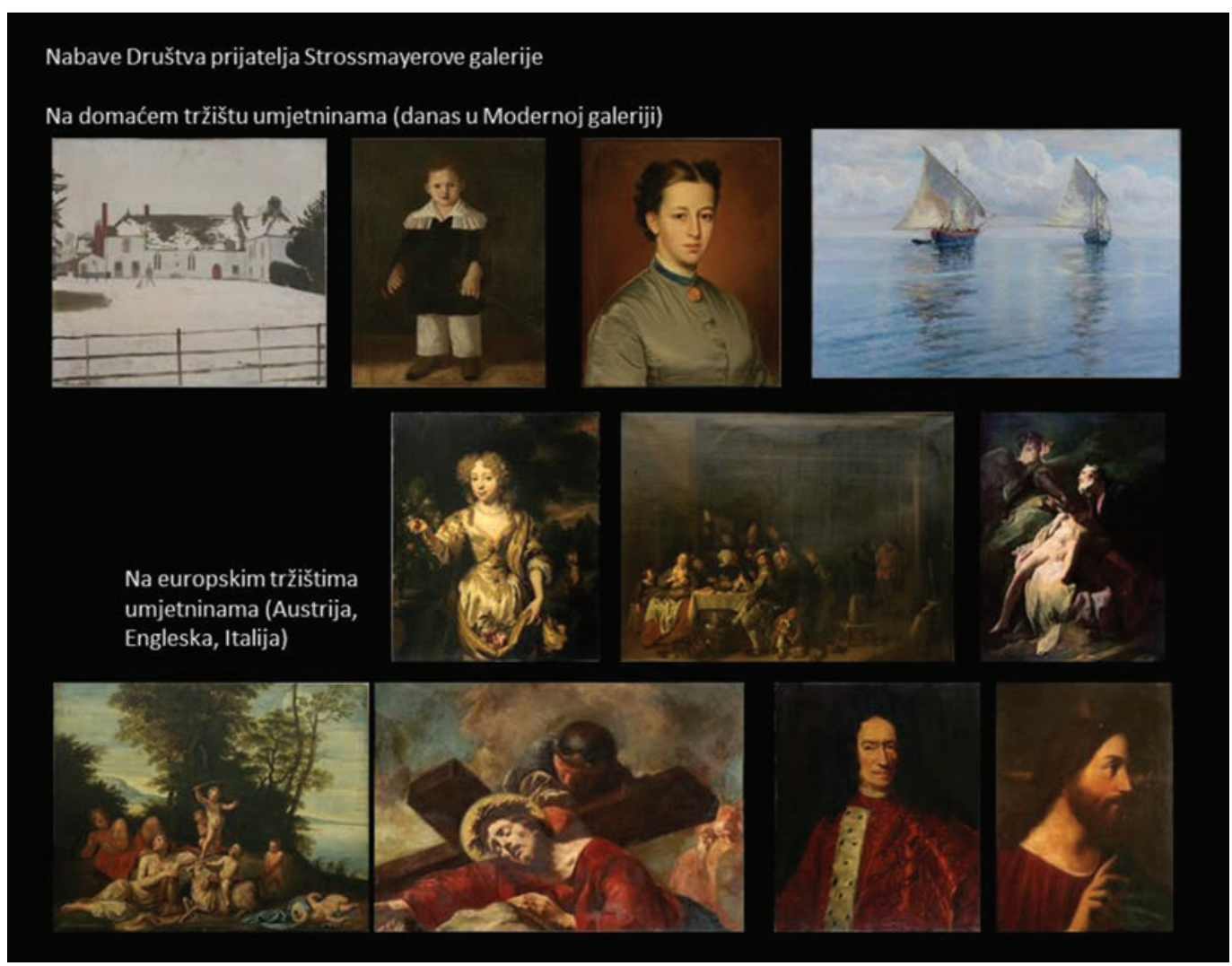

Sl. 2. Nabave Društva prijatelja Strossmayerove galerije

Daljnjim istraživanjem potvrđuje se da je nekolicina aktivnih članova Društva imala značajne vlastite privatne zbirke posve kolekcionarskoga karaktera. Aktivni ponajviše na bečkom umjetničkom tržištu, skupljači poput industrijalca Ervina Weissa (1884. - 1966.), koji je bio blagajnik Društva, nisu nabavljali umjetnine samo za osnovnu dekoraciju svojih stambenih prostora, već su formirali znalačke umjetničke zbirke. ${ }^{9}$ U takvim se zbirkama češće nalaze i djela starih majstora, ne samo na temelju obiteljskog nasljedstva već i nabavljena na suvremenim europskim tržištima. Tako je, primjerice, jednu od slika u svojoj zbirci Ervin Weiss kupio u Beču 1925. godine na prodaji zbirke berlinskog tvorničara tekstila Jacquesa Mühsama pri aukcijskoj kući Auktionshaus für Altertümer Glückselig. ${ }^{10}$

Usporedno možemo pratiti razvoj zajedničkog jugoslavenskog tržišta umjetninama, ne samo na osnovi jugoslavenskih umjetničkih izložbi prodajnoga karaktera ili, pak, pojedi-

$\overline{9}$ Ervin Weiss svoju je zbirku formirao u Beču tijekom 1920-ih i 1930-ih godina 20. stoljeća, ponajviše kupujući u starinarnici i na dražbama aukcijske kuće koju su vodila braća Max i Samuel Glückselig. Više o sudbini zbirke Ervina Weissa v. I. PAsini TržEc, „Contentious musealisation process(es) of Jewish Art Collections in Croatia“, Studi di Memofonte (u tisku); Ista, „Private Collections of Public Interest' in Zagreb and Their Destiny under Socialism“, Acta historiae artis Slovenica (u tisku).

10 Usp. Borivoj PopovČak, I. Pasıni TrŽEc i Lj. Dulibić, Portreti u Strossmayerovoj galeriji / katalog izložbe, Zagreb 2018., 20-22. 
načnih ponuda individualnih prodavatelja, već i slijedom okolnosti koje su u međuratnom razdoblju dovele do čitavoga vala organiziranih prodaja. U Sloveniji je uslijed promijenjenih političkih okolnosti nakon formiranja zajedničke jugoslavenske države donesen čitav niz mjera koje su pospješile ekonomsku propast aristokratskih obitelji te posljedično dovele do napuštanja dvoraca i prodaje cjelokupnih inventara. ${ }^{11}$ Sudski vođene organizirane dražbe sustavno su se pratile preciznim katalozima. Zainteresirani kupci na tim aukcijama bili su i zagrebački kolekcionari i trgovci umjetninama.

Tako je 1930. godine rasprodana zbirka obitelji Strahl iz dvorca Stara Loka. ${ }^{12}$ Jedan od kupaca bio je zagrebački antikvar Stanko Senečić, posebno zainteresiran za trgovinu djelima starih majstora. Od tridesetak slika, koliko ih je Senečić kupio u dvorcu Stara Loka, pet ih je danas prepoznato u Muzeju za umjetnost i obrt, u čiji su fundus prispjele na različite načine i $u$ različito vrijeme. ${ }^{13}$ Dva portreta identificirana su kao nekadašnje vlasništvo Milana Marića (1885. - 1945.), gospodarstvenika

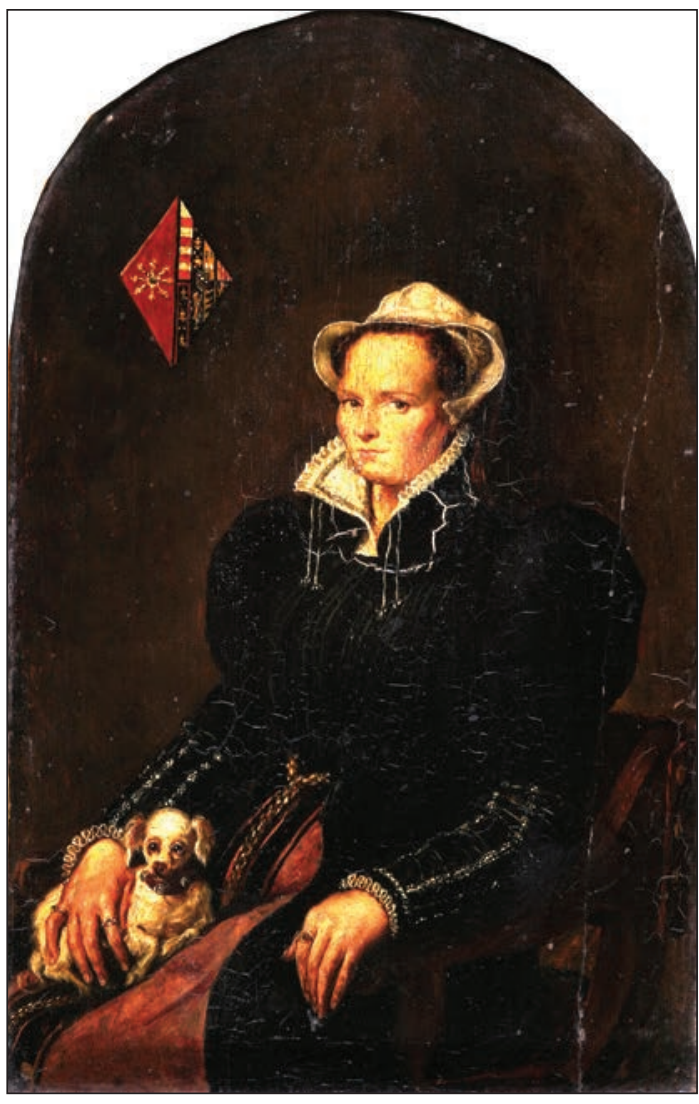

Sl. 3. Prema: Antonio Moro, Portret žene spsićem $u$ krilu, nakon 1555., ulje na dasci, $18,5 \times 12,5 \mathrm{~cm}$, Strossmayerova galerija starih majstora HAZU, inv. br. SG-706. (foto: Strossmayerova galerija) iz židovske obitelji Mayer. ${ }^{14}$ Do 1935. jedan od glavnih upravitelja sisačkoga Shella, Marić je neposredno nakon izbijanja rata uspio pobjeći iz Jugoslavije, zatraživši kao turski konzul utočište u Istanbulu. ${ }^{15}$ Umjetnine iz njegove zbirke ubrzo su pohranjene u Muzej za umjetnost i obrt. ${ }^{16}$

11 Usp. Renata Komić Marn i Tina KošAK, „Zbirka Ladislava grofa Szapáryja v gradu Murska Sobota. Ishodišča za nadaljnje raziskovanje“, Umetnostna kronika, 58/2018., 13-19.

12 Više o zbirci obitelji Strahl usp. R. Komić Marn, Strahlova zbirka v Stari Loki in njena usoda po letu 1918, Ljubljana 2016. (doktorska disertacija)

13 Isto.

14 Riječ je o slikama: Neznani slikar 17. st., Janez Erazem barun Engelshaus, Renata Leopoldina barunica Engelshaus, Muzej za umjetnost i obrt (dalje: MUO), inv. br. MUO-14899 i MUO-14898. Više o Milanu Mariću usp. Snješka KneŽEvić i Aleksandar Laslo, Židovski Zagreb. Kulturno-povijesni vodič, Zagreb 2011., 49; Goran Bilogrivić, „Ulomak pluteja s prikazom lova na jelena iz Novigrada i ljetnikovac Werner u Zagrebu“, Radovi Instituta za povijest umjetnosti, 38/2014., 46.

15 Usp. Mira Kolar-Dimitrijević, „Strani kapital i Banovina Hrvatska 1939-1941.“, Povijesni prilozi, 9/1990., 178.

16 Usp. Preporuka nakon pohrane zbirke Milana Marića u Muzej za umjetnost i obrt, 29. srpnja 1941. Ministarstvo kulture, Uprava za zaštitu kulturne baštine, Središnji arhiv, Dokumentacijska građa Konzervatorskog ureda (dalje: MK-UZKB/SA-ZSG), 1941., 1-300, 150/1941. 
Naime, Muzej za umjetnost i obrt tijekom Drugoga svjetskog rata djelovao je kao sabirni centar za pohranu umjetnina, do čijeg je transfera, bilo dobrovoljnog ili, pak, prisilnoga, došlo slijedom uspostave Nezavisne Države Hrvatske. ${ }^{17}$ Već u svibnju 1941. donesena je Zakonska odredba o zabrani otudivanja i izvažanja starinskih umjetničkih, kulturno-povijesnih i prirodnih spomenika na području $\mathrm{NDH} .{ }^{18}$ Osim zabrane izvoza, tom su zakonskom odredbom „sve $\mathrm{dr}$ žavne, samoupravne i vjerske ustanove" bile pozvane čuvati i na sigurna mjesta pohranjivati starinske umjetničke, kulturno-povijesne i prirodne spomenike. Isto je vrijedilo i za privatne osobe te sve njihove umjetnine, pa i one koje ,imadu izričito porodični i lični karakter“ ${ }^{19}$ Ako se ustanove i privatnici nisu mogli sami brinuti o umjetničkim i prirodnim spomenicima, bili su dužni predati ih „kojem od hrvatskih narodnih muzeja ${ }^{\text {“ }}{ }^{20}$ Konzervatorski je zavod na osnovi te zakonske odredbe donio odluku „da se svi predmeti umjetničke, kulturno-historijske i prirodne važnosti koji se nalaze u privatnom posjedu (...) imadu pregledati, popisati, te $\mathrm{u}$ slučaju nedovoljne zaštićenosti istih prenijeti u za to određene ustanove ${ }^{\text {“21 }}$ te $s$ tim u vezi izdao „Upozorenje vlasnicima starina“, kojim su „posjednici starina“ upozoreni „da ne izbjegavaju popisu, nego da idu na ruku izaslanicima zavoda, i olakšaju im rad.“22

Stvarna svrha popisivanja bila je pohranjivanje umjetničkih predmeta iz privatnog vlasništva u muzej, a iste su se odredbe koristile i kao „pravno uporište“ za oduzimanje umjetnina iz židovskoga vlasništva. Nakon pohranjivanja u Muzej za umjetnost i obrt umjetnina pokojnih, neprisutnih ili izbjeglih osoba tijekom 1941. godine, 1942. godine slijedile su prisilne pohrane. ${ }^{23}$ Tako pohranjene, odnosno oduzete umjetnine dočekale su kraj Drugoga svjetskoga rata u Muzeju, kada je ostvareno svega nekoliko povrata.

U novoj su jugoslavenskoj državi ostvareni novi transferi (vlasništva) umjetnina i njihova redistribucija primjenom različitih mehanizama razvlašćivanja privatnoga vlasništva (nacionalizacija, eksproprijacija, sekvestracija i konfiskacija). ${ }^{24} \mathrm{Na}$ temelju Odluke o prelazu u državnu svojinu neprijateljske imovine, o državnoj upravi nad imovinom neprisutnih lica i o sekvestru nad imovinom koju su okupatorske vlasti prisilno otudile donesen je u svibnju 1945. godine Zakon o pribiranju, čuvanju i raspodjeli knjiga i drugih kulturno-naučnih i umjetničkih predmeta, kojim se predmeti umjetničke vrijednosti izdvajaju od ostale podržavljene

17 Božidar Murgić, Izvještaj o provedbi zakonske odredbe o zabrani otuđivanja i izvažanja starinskih umjetničkih, kulturno-povjesnih i prirodnih spomenika na području Nezavisne Države Hrvatske, LXXVIII-135 Z.p./1941., 12. svibnja 1941., 26. srpnja 1941. Hrvatski državni arhiv (dalje: HR-HDA-1149), fond Zbirka Božidara Murgića o muzejskoj djelatnosti u Hrvatskoj od 1920-ih do 1940-ih, kut. 1. Usp. I. PASINI TRŽEC, „Contentious musealisation process(es)“.

18 Usp. Martina Juranović-Tonejc, „Zakonska regulativa u zaštiti pokretne baštine u doba Nezavisne države Hrvatske“, Godišnjak zaštite spomenika kulture Hrvatske, 33-34/2012., 15-22.

19 Zakonska odredba o zabrani otuđivanja i izvažanja starinskih umjetničkih, kulturno-povjesnih i prirodnih spomenika na području Nezavisne Države Hrvatske, LXXVIII-135 Z.p./1941., 12. svibnja 1941.

20 Isto

21 Odluka Konzervatorskoga zavoda, 17. svibnja 1941. MK-UZKB/SA-ZSG, 1941., 1-300, 84/1941.

22 Upozorenje vlasnicima starina. MK-UZKB/SA-ZSG, 1941., 1-300, 90/1941.

23 Usp. I. PAsini TrŽEC, „Contentious musealisation process(es)“.

24 Usp. Tomislav AnIĆ, „Normativni okvir podržavljenja imovine u Hrvatskoj/Jugoslaviji 1944.-1946.“, Časopis za suvremenu povijest, 39/2007., br. 1, 25-62; Marijan MatickA, „Zakonski propisi o vlasničkim odnosima u Jugoslaviji (1944-1948)“, Radovi Zavoda za hrvatsku povijest Filozofskog fakulteta u Zagrebu, 25/1992., 123-148; Naida MinaL BRANDL, „Jews between two totalitarian systems: property legislation“, Review of Croatian history, 12/2016., 106127. 
imovine i stavljaju u nadležnost Ministarstva prosvjete. ${ }^{25} \mathrm{Zbog}$ toga je osnovana KOMZA - Komisija za sakupljanje i zaštićivanje kulturnih spomenika i starina, koja je, osim redistribucije ranije oduzete židovske imovine zatečene u Muzeju za umjetnost i obrt, izdvajala predmete umjetničkoga karaktera iz poratno oduzimane imovine. ${ }^{26}$

Prvi neposredan cilj poslijeratne konfiskacije, kao mjere oduzimanja dijela ili cjelokupne imovine bez naknade u korist države, bio je kazniti vojne zločince i narodne neprijatelje, međutim, kako je ubrzo ustanovljeno da je „pravih izdajnika među klasnim neprijateljima (...) premalo“, imovina se oduzimala na „manipulatorski način“, pod izlikom suradnje s okupatorom, kako bi se ograničilo privatno vlasništvo, odnosno doslovno „uništili privatnici“ ${ }^{27}$

Tako je oduzeta čitava zbirka Branke i Ervina Weissa, formirana tijekom 1920-ih i 1930ih godina, iako je nakon rata dobila status zaštićene privatne zbirke javnoga karaktera. ${ }^{28}$ Četristo četrdeset i pet kulturno-povijesnih, umjetničkih te predmeta dnevne uporabe iz zbirke Branke i Ervina Weissa bilo je razdijeljeno među različitim ustanovama u Zagrebu. Naime, nakon izdvajanja predmeta koje bi KOMZA ocijenila „umjetničkim“, slijedila je distribucija u muzejske ustanove, s obzirom na vrstu i tip građe: portreti bi se tako transferirali u Hrvatski povijesni muzej, slike starih majstora u Strossmayerovu galeriju, djela modernih i suvremenih slikara i kipara u Modernu galeriju, a djela umjetničkoga obrta u Muzej za umjetnost i obrt.

Poteškoće u današnjoj rekonstrukciji tako raspršenih zbirki uzrokuje, između ostaloga, i činjenica da se ni to načelo distribucije nije uvijek poštovalo, što je pridonijelo posvemašnjem gubitku memorije ne samo na izvlaštene privatne zbirke već i na ranije podrijetlo umjetnina u tim zbirkama. Tako je, primjerice, serija portreta habsburških vladara koja potječe iz dvorca Pukštanj pri Bukovju kod Dravograda opetovano fragmentirana slijedom poratne redistribucije umjetnina nekada u vlasništvu zagrebačkog kolekcionara i potomka ugledne židovske obitelji Roberta Deutscha Maceljskog. ${ }^{29}$ Nakon rasprodaje cjelokupnoga inventara dvorca Pukštanj 1932. godine, do koje je došlo uslijed opadanja ekonomske stabilnosti aristokratskih obitelji u Sloveniji, četiri portreta habsburških vladara (Rudolfa II., Karla V., Maksimilijana II. i Alberta Austrijskog) dospijevaju u zbirku Roberta Deutscha, koja je uspostavom Nezavisne Države Hrvatske najprije popisana i fotografirana, a potom 1942. godine preuzeta i pohranjena u Muzeju za umjetnost i obrt. ${ }^{30}$ Nedugo nakon završtetka Drugog svjetskog rata dio zbirke Deutscha Maceljskog preuzela je Strossmayerova galerija. U Muzeju za umjetnost i obrt ostali su portreti Rudolfa II. i Maksimilijana II., ${ }^{31}$ a portreti Alberta Austrijskog i Karla V. danas su u Strossmayerovoj galeriji. ${ }^{32}$

25 HR-HDA-291, fond Ministarstvo prosvjete Narodne Republike Hrvatske (dalje: MinPrNRH), kut. 58.

26 HR-HDA-291, MinPrNRH, kut. 68. Usp. I. PAsini TRŽEC, „Redistribution of cultural objects in Yugoslavia after 1945", Zadar Summer School Provenance, why does it matter? Provenance, Dispossession and Translocation Research, Zadar, 27. - 31. kolovoza 2018.

27 Zdenko Radelić, Hrvatska u Jugoslaviji 1945.-1991. Od zajednistva do razlaza, Zagreb 2006., 61.

28 Usp. I. PAsini TrŽEC, „Contentious musealisation process(es)“; IsTA, „Private Collections of Public Interest”“. Usp. B. Popovčak, I. Pasini Tržec i Lj. Dulibić, Portreti u Strossmayerovoj galeriji, 23-28.

Isto, 28.

31 Neznani slikar, RudolfII., ulje na platnu, 61,5 x $53 \mathrm{~cm}$, Zagreb, MUO, inv. br. MUO-025808; Neznani slikar, Maksimilijan II., ulje na platnu, 61,5 x $53 \mathrm{~cm}$, Zagreb, MUO, inv. br. MUO-0258156.

32 Neznani slikar, Albert Austrijski, ulje na platnu, $61,5 \times 52,8 \mathrm{~cm}$, Strossmayerova galerija starih majstora HAZU, inv. br. SG-385; Neznani slikar, Karlo V., ulje na platnu, $62,8 \times 52,8 \mathrm{~cm}$, Strossmayerova galerija starih majstora HAZU, inv. br. SG-384. 


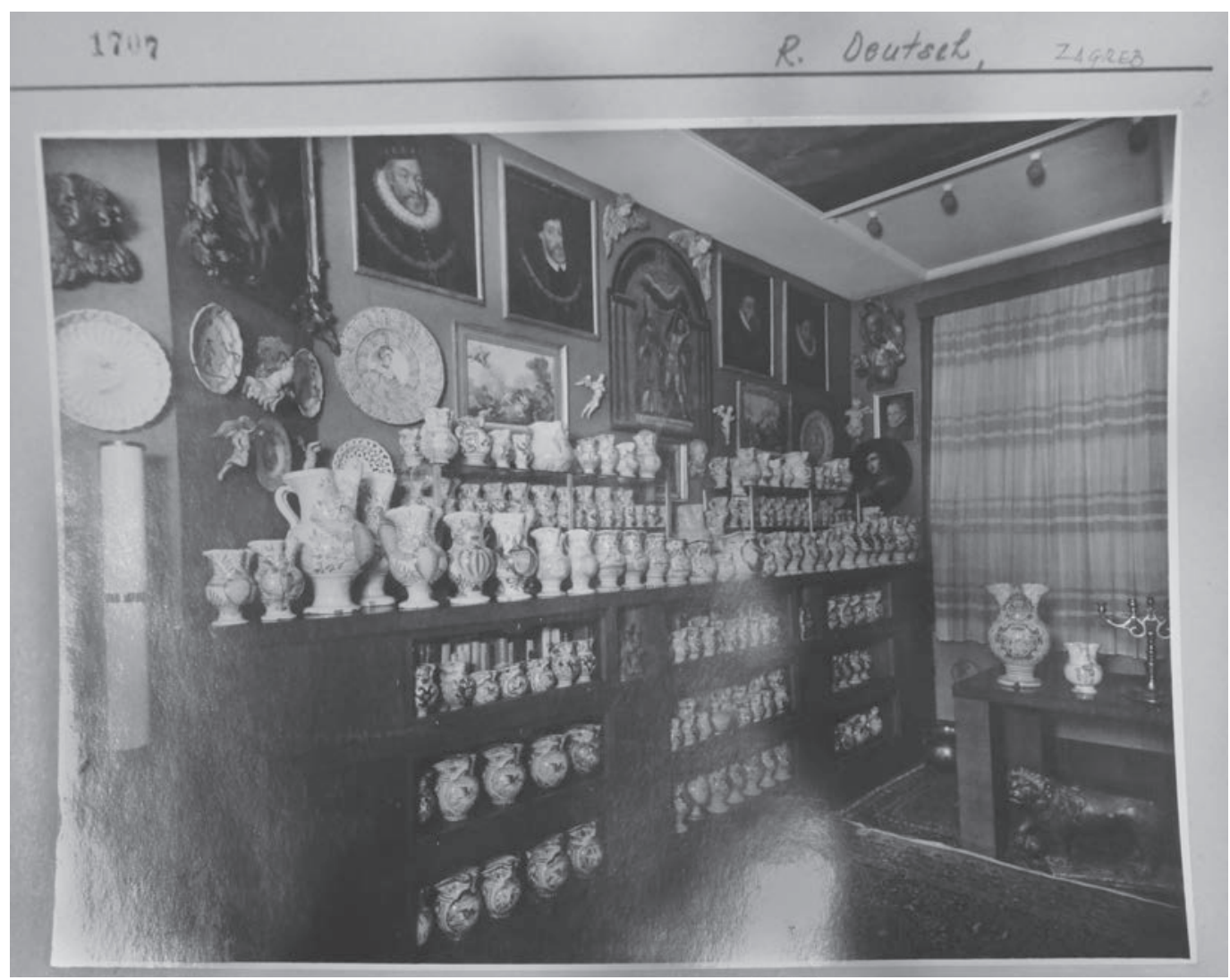

Sl. 4. Umjetnine u stanu Roberta Deutscha Maceljskog, 1941.

Ministarstvo kulture, Uprava za zaštitu kulturne baštine, Služba za dokumentaciju, registar i promociju kulturne baštine, Zbirka fotografske dokumentacije (dalje: MK-UZKB-F), Deutsch, 1707.

Masovnim registriranjem privatnih zbirki, do čega dolazi neposredno nakon rata, pokušavalo se zaštititi pravo vlasništva, odnosno raspolaganja vlastitim stambenim prostorima. ${ }^{33}$ KOMZA-in je zadatak bio popisati predmete umjetničke vrijednosti te izdati preporuku za zaštitu koja je onemogućavala useljavanje prisilnih sustanara. ${ }^{34}$ Zaštite zbirki unutar privatnih stambenih prostora često su kasnije dovele do iznuđenih donacija i/ili otkupa, kako bi vlasnici mogli isposlovati mogućnost slobodnoga raspolaganja barem jednim dijelom zbirke. Naime, da bi ishodili dozvolu za izvoz umjetnina (i time si omogućili prodaju na stranim tržištima), barem dio umjetnina iz svojih zbirki ustupili bi muzejskim institucijama u obliku donacije i/ili otkupa, u dogovoru s nadležnim konzervatorskim zavodom. ${ }^{35}$

33 Usp. Veljko Minalıć, „Privatne zbirke darovane gradu Zagrebu i njihova uloga u kulturnom razvoju grada“, Muzeologija, 45/2008., 25, bilj. 2; I. PAsInI TRŽEC, „Private Collections of Public Interest'“.

34 Kompletna dokumentacija koja je nastala djelovanjem KOMZA-e nalazi se u zatvorenim zbirkama starije građe Ministarstva kulture (https://www.min-kulture.hr/default.aspx?id=396), a dio KOMZA-inih dokumenata dostupan je u HR-HDA-291, fond MinPrNRH.

35 I. PAsini TRŽEC, „'Private Collections of Public Interest"“. 
Tako je učinila i Kamila Radovan (1902. - 1998.), čiji je slučaj rječito svjedočanstvo poslijeratne preraspodjele stambenoga fonda, različitih faza i metoda razvlašćivanja te, posljedično tome, i rasparčavanja zbirke. ${ }^{36}$ Kamila i njezin suprug Eugen Radovan (1874. - 1947.), potomak stare židovske obitelji Rosenberg, pripadali su najimućnijim građanima prijeratnog Zagreba. ${ }^{37}$ Eugen je bio dioničar i suvlasnik više tvrtki, između ostaloga, i glavni zastupnik Boscha, čiji je znak bio istaknut na prvome zagrebačkom neboderu koji je Eugen dao sagraditi prema projektu arhitekta Slavka Löwyja.

Eugenova mlada supruga Kamila bila je istaknuta predstavnica tadašnjeg mondenog života grada Zagreba, a Eugen pokrovitelj mnogih kulturnih društava, između ostaloga, i jedan od osnivača Društva prijatelja Strossmayerove galerije. Posjedovali su znalački formiranu umjetničku zbirku u kojoj su bile zastupljene umjetnine od antike do kasnoga baroka.

Uspostavom Nezavisne Države Hrvatske Zbirka Radovan je popisana te su načinjene fotografije interijera njihove vile na Josipovcu (danas Nazorova ulica, br. 56) u Zagrebu. ${ }^{38}$

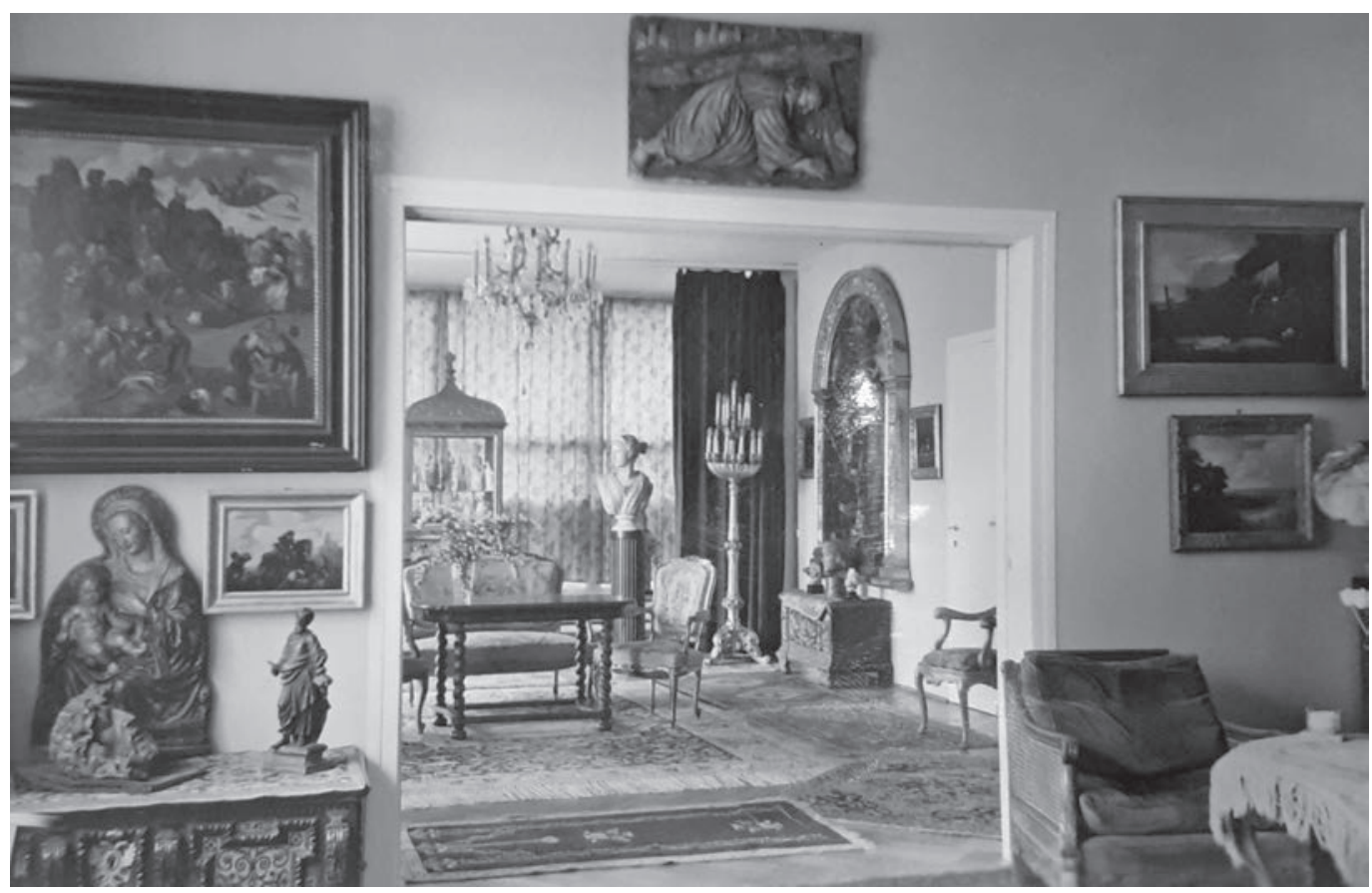

Sl. 5. Interijer vile Radovan, 1941.

MK-UZKB-F, Zbirka Radovan, 281/45.

36 O sudbini Zbirke Radovan v. Isto; Ista, „O sudbini jedne zagrebačke zbirke / On the fate of a collection from Zagreb“ (https://www.transcultaa.eu/wp-content/uploads/2018/09/poster09.pdf).

37 „Radovan, Eugen“, Židovski biografski leksikon (http://zbl.lzmk.hr/?p=1712)

38 Popis Zbirke Radovan od 21. svibnja 1941. čuva se u različitim arhivskim fondovima: MK-UZKB/SA-ZSG, 1941., 1-300, 93/1941; HR-HDA-1076, fond Ministarstvo državne riznice NDH. Odjel za novčarstvo, državnu imovinu i dugove. Ured za podržavljeni imetak (dalje: PONOVA), kut. 694, Rosenberg Kamila. Fotografije interijera vile u Nazorovoj 56 čuvaju se u fototeci Ministarstva kulture Republike Hrvatske. Ministarstvo kulture, Uprava za zaštitu kulturne baštine, Služba za dokumentaciju, registar i promociju kulturne baštine, Zbirka fotografske dokumentacije (dalje: MK-UZKB-F), Zbirka Radovan. 
Vilu je početkom rata zaposjeo njemački Wehrmacht, no većina je umjetnina dočekala 1945. godinu u istom prostoru, iako je nekoliko predmeta iz vile bilo nestalo. ${ }^{39}$ Nakon proglašenja Federativne Narodne Republike Jugoslavije, Zbirka Radovan registrirana je i zaštićena kao „privatna zbirka javnoga značaja“, čime se trebala osigurati ne samo zaštita predmeta već i njihova razmještaja, a time i čitave vile. ${ }^{40}$ Eugen umire 1947. godine, a Kamili Radovan je - unatoč zaštiti - početkom 1949. godine vila oduzeta te je ona useljena u Vilu Arko u Basaričekovoj 24, gdje je do tada bilo jedno od skladišta KOMZE. ${ }^{41}$

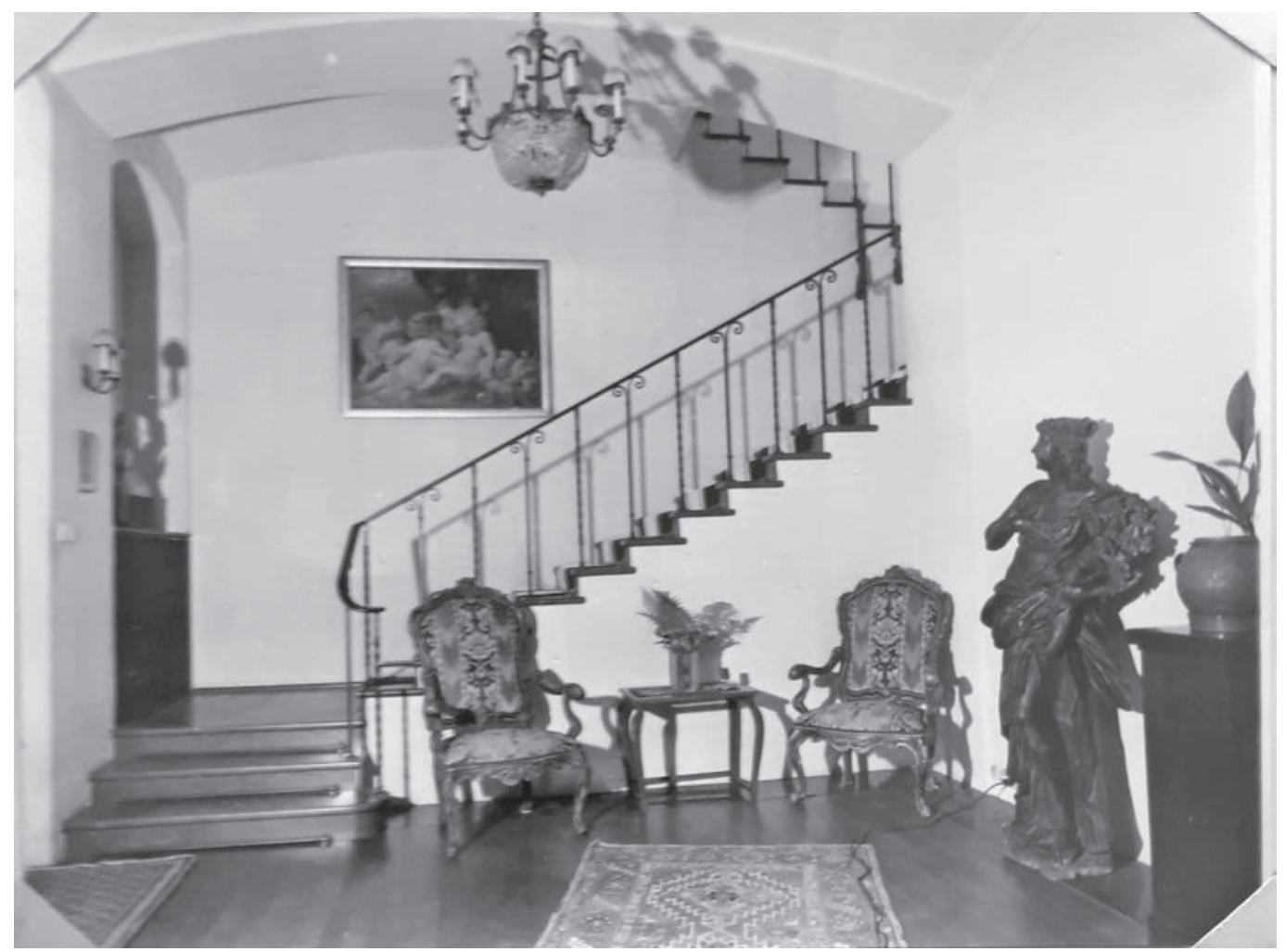

Sl. 6. Interijer, Basaričekova 24, 1976.

Gradski zavod za zaštitu spomenika kulture i prirode, Zagreb (GZZSKP),

Odjel za dokumentaciju, Zbirka Radovan

Međutim, zgradu u Basaričekovoj 24 je 1976. godine Skupština grada Zagreba odredila za smještaj Zbirke Ante Topića Mimare te je Kamila Radovan ponovno bila primora-

39 V. „Yugoslavian Fine Arts Claims made to Austria, property of Kamilla Radovan“ (https://www.fold3.com/image/274421468); Izvještaj KOMZA-e, 20. veljače 1945. Gradski zavod za zaštitu spomenika kulture i prirode, Zagreb, Odjel za dokumentaciju (dalje: GZZSKP-Odjel za dokumentaciju), Zbirka Radovan.

40 Rješenje o zaštiti umjetničkih predmeta iz Zbirke Radovan doneseno je 8. listopada 1945., a Zbirka Radovan proglašena je javnom 18. listopada 1947. te je nekoliko dana kasnije, 27. listopada, i otvorena za javnost. Usp. MK-UZKB/ SA-ZSG, Urudžbeni zapisnici Konzervatorskoga zavoda, 1945. - 1947.; 1947. - 1949.

41 Usp. Konzervatorski zavod Stambenom otsjeku, 8. lipnja 1948.; 30. listopada 1948.; Konzervatorski zavod Ministarstvu prosvjete, 3. prosinca 1948. HR-HDA-291, MinPrNRH, kut. 63 i 65; Muzej grada Zagreba, Izvještaj o preuzimanju predmeta iz Zbirke Radovan, 31. siječnja 1949. GZZSKP-Odjel za dokumentaciju, Zbirka Radovan. 
na iseliti se. Tada, izgleda, konačno odustaje od života u Zagrebu i traži dozvolu za izvoz umjetnina u Beč. Iako je nadležna komisija predložila zabranu izvoza za desetak umjetnina iz zbirke, Kamili Radovan njihov izvoz u Beč nije bio uskraćen jer je „zahtjevu [bila] priložena preporuka Republičkog sekretarijata za prosvjetu, kulturu i fizičku kulturu da se u ovom izuzetnom slučaju odobri izvoz umjetnina (...) budući da se istim iseljenjem vlasnice predmeta rješavaju potrebe zbirke Ante Topić-Mimare, koja je akcija od posebnog interesa za Republiku i za Grad Zagreb.“42

Zbirka Radovan je, međutim, do tada već bila djelomično rasparčana, uslijed ranijih pohrana dijela predmeta iz zbirke u muzeje i otkupa koje je Kamila bila uspjela dogovoriti. Sudbina dijela zbirke koji je izvezen 1976. godine još nam je uvijek nepoznata.

Predstavljeni slučajevi ukazuju na različite mehanizme razvlašćivanja, čija je posljedica disperzija umjetnina, brisanje tragova vlasništva, razjedinjenost materijala, čupanje iz autentičnoga prostora... To je tek malen dio gotovo nepreglednoga pokretnoga kulturnoga nasljeđa nekada u privatnom vlasništvu, koje je nakon turbulentnih ratnih i poratnih zbivanja na različite načine dospjelo u razne muzejske institucije, gdje im se u pravilu gubi memorija na nekadašnji kontekst.

Transferi umjetnina svjedočanstvo su povijesnoga razdoblja u kojem je došlo do promjene društvene i kulturne slike grada Zagreba, čijem razumijevanju - između ostaloga može pridonijeti istraživanje itinerarija pojedinih predmeta u javnim i privatnim zbirkama te administrativnoga ustroja, unutar kojega operativno i institucionalno djeluju povijest umjetnosti i srodne discipline u procesima izvlašćivanja umjetničkih predmeta.

\section{$\cos$}

\section{THE TRANSFERS OF OWNERSHIP OF WORKS OF ART AND ART COLLECTIONS IN ZAGREB BEFORE, DURING AND AND AFTER THE SECOND WORLd WAR}

Summary: This paper is based on the research of the inter-war art market in Zagreb as a cultural center of growing significance in the Yugoslav context. It focuses particularly on the processes of transfer, translocation, removal and expropriation of works of art, as part of the larger tendency towards property expropriation during and after World War II, instigated by two totalitarian regimes. Additionally, the work of certain societies and individuals on the local and international art market in the 1920s and 1930s is analyzed, as it reflects the wider context of social changes which generated the change of ownership of individual works of art and entire collections. The paper

2 Usp. Izvještaj o otkupu umjetnina, 1967.; Lista 67 umjetnina planiranih za izvoz. GZZSKP-Odjel za dokumentaciju, Zbirka Radovan. 
focuses on the private collections that had been formed in Zagreb between the two world wars, and on what became of them later. Similar outcomes were brought about not only by the expropriation of Jewish property during World War II, but other types of postwar appropriation as well - those due to immigration, emigration, sequestration and confiscation. The dispersion of artworks and the erasure of previous ownership records are all symptoms of a period of history that was marked by the desire to exert control over remaining pockets of private ownership, in the context of changing social mores the nationalization processes in the economy in general.

The cases analyzed here are but a small portion of a vast cultural heritage, formerly in private ownership, which ended up in various museums during the turmoil of wartime and the postwar period, where, as a general rule, all memory of their original context was lost. These changes of ownership of works of art attest to the changes in the social and cultural outlook of Zagreb in that era. It is precisely those changes that researching the itinerary of certain objects, be it in museums or private collections, can shed a light on, as can the analysis of the administrative system within which art history and related disciplines contributed to the process of expropriation.

Key words: Zagreb, the international art market, The Society of Friends of the Strossmayer Gallery, private art collections, the expropriation of private property, art transfer, World War II, the postwar period

\section{$\cos$}

\section{Izvori}

Gradski zavod za zaštitu spomenika kulture i prirode, Zagreb (GZZSKP), Odjel za dokumentaciju, Zbirka Radovan

Hrvatski državni arhiv (HR-HDA)

HR-HDA-291, fond Ministarstvo prosvjete Narodne Republike Hrvatske (MinPrNRH), kut. 58.

HR-HDA-291, fond Ministarstvo prosvjete Narodne Republike Hrvatske (MinPrNRH), kut. 63.

HR-HDA-291, fond Ministarstvo prosvjete Narodne Republike Hrvatske (MinPrNRH), kut. 65.

HR-HDA-291, fond Ministarstvo prosvjete Narodne Republike Hrvatske (MinPrNRH), kut. 68.

HR-HDA-1076, fond Ministarstvo državne riznice NDH. Odjel za novčarstvo, državnu imovinu i dugove. Ured za podržavljeni imetak (PONOVA), kut. 694.

HR-HDA-1149, fond Zbirka Božidara Murgića o muzejskoj djelatnosti u Hrvatskoj od 1920-ih do 1940 -ih, kut. 1.

Ministarstvo kulture, Uprava za zaštitu kulturne baštine, Služba za dokumentaciju, registar i promociju kulturne baštine, Zbirka fotografske dokumentacije (MK-UZKB-F), Zbirka Radovan

Ministarstvo kulture, Uprava za zaštitu kulturne baštine, Središnji arhiv, Zbirke starije građe, Dokumentacijska građa Konzervatorskog ureda (MK-UZKB/SA-ZSG)

MK-UZKB/SA-ZSG, 1941., 1-300, 84/1941.

MK-UZKB/SA-ZSG, 1941., 1-300, 90/1941.

MK-UZKB/SA-ZSG, 1941., 1-300, 93/1941.

MK-UZKB/SA-ZSG, 1941., 1-300, 150/1941. 
MK-UZKB/SA-ZSG, Urudžbeni zapisnici Konzervatorskoga zavoda, 1945. - 1947.; 1947. 1949.

Muzej za umjetnost i obrt (MUO), inv. br. MUO-14899; MUO-14898; MUO-025808; MUO0258156.

Strossmayerova galerija starih majstora HAZU, inv. br. SG-384; SG-385.

Zakonska odredba o zabrani otuđivanja i izvažanja starinskih umjetničkih, kulturno-povjesnih i prirodnih spomenika na području Nezavisne Države Hrvatske, LXXVIII-135 Z.p./1941., 12. svibnja 1941.

Svijet: ilustrovani tjednik, 2/(2. srpnja) 1927., br. 15, 11.

\section{Literatura}

Tomislav Anić, „Normativni okvir podržavljenja imovine u Hrvatskoj/Jugoslaviji 1944.-1946.“, Časopis za suvremenu povijest, 39/2007., br. 1, 25-62.

Goran BiLogrivić, „Ulomak pluteja s prikazom lova na jelena iz Novigrada i ljetnikovac Werner u Zagrebu“, Radovi Instituta za povijest umjetnosti, 38/2014., 41-50.

Ljerka DulıBıć, „Međuratno jugoslavensko tržište umjetninama“, 8. posvet slovenskih umetnostnih zgodovinarjev. Provenienca, transferji in lastništvo umetnin. Sodobni izzivi za raziskovalce in lastnike, Maribor, 30. studenoga - 1. prosinca 2018.

Ljerka Dulıbić, „Projekat 'Prenos kulturnih dobara u Alpe-Adria regionu u XX veku' ('TransCultAA')“, Stubovi baštine. Glasnik Zavoda za zaštitu spomenika kulture Nišs, 3/2017., br. 3, 70-75.

Ljerka Dulibić i Iva PAsini TrŽEC, „Akvizicije Društva prijatelja Strossmayerove galerije“, u: Imago, imaginatio, imaginabile. Zbornik u čast Zvonka Makovića (ur. Dragan Damjanović i Lovorka Magaš Bilandžić), Zagreb 2018., 281-301.

Ljerka Dulibić i Iva PAsıni TržEc, „Schneiderovi prilozi za Strossmayerovu galeriju starih majstora", u: Zbornik radova znanstveno-stručnog skupa Hrvatski povjesničari umjetnosti 1. Artur Schneider (1879.-1946.) (ur. Ljerka Dulibić), Zagreb 2016., 71-79.

Martina Juranović-ToneJC, „Zakonska regulativa u zaštiti pokretne baštine u doba Nezavisne države Hrvatske“, Godišnjak zaštite spomenika kulture Hrvatske, 33-34/2012., 15-22.

Snješka KneŽEvić i Aleksandar Laslo, Židovski Zagreb. Kulturno-povijesni vodič, Zagreb 2011.

Mira Kolar-Dimitrijević, „Strani kapital i Banovina Hrvatska 1939-1941.“, Povijesni prilozi, 9/1990., 165-194.

Renata Komić Marn, Strahlova zbirka v Stari Loki in njena usoda po letu 1918, Ljubljana 2016. (doktorska disertacija)

Renata Komić Marn i Tina KošAK, „Zbirka Ladislava grofa Szapáryja v gradu Murska Sobota. Ishodišča za nadaljnje raziskovanje“, Umetnostna kronika, 58/2018., 13-19.

Marijan MAтіскA, „Zakonski propisi o vlasničkim odnosima u Jugoslaviji (1944-1948)“, Radovi Zavoda za hrvatsku povijest Filozofskog fakulteta u Zagrebu, 25/1992., 123-148.

Naida Minal Brandl, „Jews between two totalitarian systems: property legislation“, Review of Croatian history, 12/2016., 106-127.

Veljko Minalić, „Privatne zbirke darovane gradu Zagrebu i njihova uloga u kulturnom razvoju grada“, Muzeologija, 45/2008., 1-267.

Iva PAsini TržEc, „Contentious musealisation process(es) of Jewish Art Collections in Croatia“, Studi di Memofonte (u tisku). 
Iva PAsini Tržec, „Private Collections of Public Interest' in Zagreb and Their Destiny under Socialism", Acta historiae artis Slovenica (u tisku).

Iva PAsini TržEc, „Redistribution of cultural objects in Yugoslavia after 1945“, Zadar Summer School Provenance, why does it matter? Provenance, Dispossession and Translocation Research, Zadar, 27. - 31. kolovoza 2018.

Borivoj Popovčak, Iva Pasini Tržec i Ljerka Dulibić, Portreti u Strossmayerovoj galeriji / katalog izložbe, Zagreb 2018.

Zdenko Radelić, Hrvatska u Jugoslaviji 1945.-1991. Od zajedništva do razlaza, Zagreb 2006.

Žarka Vujić, Salon Ullrich o stotoj obljetnici, Zagreb 2010.

\section{Mrežne stranice}

Darija Alujević, Andreja Der-Hazarijan Vukić i Jasenka Ferber Bogdan, Salon Ullrich (http:// dizbi.hazu.hr/ullrich)

Iva PAsıni TRŽEc, „O sudbini jedne zagrebačke zbirke / On the fate of a collection from Zagreb“ (https://www.transcultaa.eu/wp-content/uploads/2018/09/poster09.pdf)

„Radovan, Eugen“, Židovski biografski leksikon (http://zbl.lzmk.hr/?p=1712) 